\title{
Protocol
}

\section{Analysis of Small RNAs by Northern Hybridization}

\author{
Chengjian Li and Phillip D. Zamore
}

This protocol describes how to use northern hybridization to detect 15- to 150-nt small RNAs. Total RNA is fractionated by electrophoresis through a denaturing polyacrylamide gel and then transferred to a nylon membrane by semidry electroblotting. After UV-cross-linking the RNA to the membrane, hybridization is performed in Church buffer using a ${ }^{32} \mathrm{P}$-radiolabeled oligonucleotide probe followed by PhosphorImager analysis. The use of StarFire probes allows a substantial increase in the specific radioactivity of the hybridization probe. StarFire probes contain two domains. The target-specific domain at the $5^{\prime}$ end hybridizes to the small RNA of interest. The universal template-binding domain at the $3^{\prime}$ end is used to bind a universal template oligonucleotide that carries 10 deoxythymidines at its $5^{\prime}$ end, providing a template for DNA polymerase to incorporate $10\left[\alpha^{-}{ }^{32} \mathrm{P}\right]$ deoxyadenosines at the $3^{\prime}$ end of the StarFire probe.

It is essential that you consult the appropriate Material Safety Data Sheets and your institution's Environmental Health and Safety Office for proper handling of equipment and hazardous materials used in this protocol.

RECIPES: Please see the end of this protocol for recipes indicated by $<R>$. Additional recipes can be found online at http://cshprotocols.cshlp.org/site/recipes.

\section{Reagents}

Acrylamide:bisacrylamide (19:1, 40\%, w/v) $\left[\alpha-{ }^{32} \mathrm{P}\right] \mathrm{dATP}(6000 \mathrm{Ci} / \mathrm{mmol}, 10 \mathrm{mCi} / \mathrm{mL})$

Ammonium persulfate $<\mathrm{R}>$

Prepare a $10 \%(w / v)$ solution.

Church buffer $<\mathrm{R}>$

Formamide loading buffer for RNA gels $<\mathrm{R}>$ $\left[\gamma^{32} \mathrm{P}\right]$ ATP $(6000 \mathrm{Ci} / \mathrm{mmol}, \geq 10 \mathrm{mCi} / \mathrm{mL})$ miRNA StarFire Nucleic Acid Labeling System (Integrated DNA Technologies; see Discussion)

StarFire Custom Probe (up to 50 nt, PAGE-purified)

StarFire Universal Template (HPLC-purified)

StarFire 10× Buffer Mix (100 mm Tris at pH 7.5, $50 \mathrm{~mm} \mathrm{MgCl}_{2}, 75 \mathrm{~mm}$ DTT)

StarFire Stop Buffer (10 mm EDTA)

Exo- Klenow DNA Polymerase

From the Molecular Cloning collection, edited by Michael R. Green and Joseph Sambrook.

(C) 2018 Cold Spring Harbor Laboratory Press

Cite this protocol as Cold Spring Harb Protoc; doi:10.1101/pdb.prot097493 
C. Li and P.D. Zamore

RNA samples and $5^{\prime 32}$ P-radiolabeled marker RNAs (e.g., RNA Decade Marker; Ambion, catalog no. AM7778)

SDS $<\mathrm{R}>$

Prepare a $20 \%(w / v)$ solution.

$\mathrm{SSC}<\mathrm{R}>$

Prepare $20 \times$ and $1 \times$ solutions.

Synthetic oligonucleotide probes (DNA, RNA, or LNA-modified DNA)

T4 polynucleotide kinase $(10 \mathrm{U} / \mu \mathrm{L})$

T4 polynucleotide kinase buffer $(10 \times)<\mathrm{R}>$

TBE buffer $<\mathrm{R}>$

Prepare $5 \times$ and $0.5 \times$ solutions.

TE buffer, $10 \times<\mathrm{R}>$

Prepare $10 \times$ and $1 \times$ solutions ( $\mathrm{pH} 8.0)$.

TEMED

Urea

Equipment

Blotting paper, extra thick

Heating block $\left(95^{\circ} \mathrm{C}\right)$

Hybridization oven (e.g., Mini Autoblot Hybridization Oven; Bellco Glass, catalog no. 7930-10110)

Hybridization tubes (e.g., Autoblot tube, $35 \times 150$ mm; Bellco Glass, catalog no. 7910-35150)

Magnetic stirrer

Nylon membrane, positively charged (e.g. Amersham Hybond N+; GE Healthcare)

PhosphorImager (e.g., FUJI FLA-5000) and software (e.g., ImageGauge v4.22)

PhosphorImager plate

Polyacrylamide gel apparatus (e.g., Bio-Rad Mini-PROTEAN, $8 \mathrm{~cm} \times 7.3 \mathrm{~cm} \times 0.75 \mathrm{~mm}$ )

Saran Wrap

Semidry transfer apparatus (e.g., Trans-Blot SD Semi-Dry Transfer Cell; Bio-Rad)

Sephadex G-25 spin columns UV cross-linker (e.g., Stratalinker UV Crosslinker; Stratagene)

METHOD

See Figure 1 for a flowchart of the procedure.

Preparation of a Denaturing Polyacrylamide Gel

1. Prepare a $15 \%$ denaturing polyacrylamide gel containing $8 \mathrm{~m}$ urea by mixing the following reagents:
TBE buffer $(5 \times)$
$2 \mathrm{~mL}$
Acrylamide:bisacrylamide (19:1, 40\%, w/v)
$3.75 \mathrm{~mL}$
Urea
$4.8 \mathrm{~g}$
Deionized water
to $10 \mathrm{~mL}$

2. Stir the mixture at room temperature with a magnetic stirrer until the urea dissolves.

3. Assemble the gel casting frame and casting stand.

4. Add $100 \mu \mathrm{L}$ of $10 \%(\mathrm{w} / \mathrm{v})$ ammonium persulfate

5. Add $10 \mu \mathrm{L}$ of TEMED. 


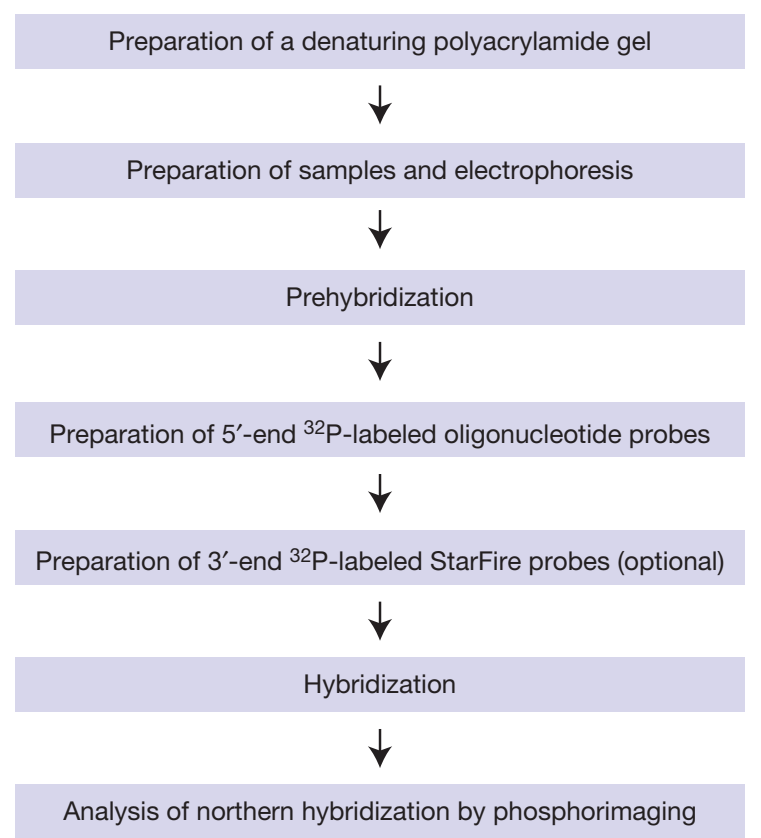

6. Mix the solution quickly, and then pour the gel into the mold of a minigel apparatus with a 10 -well comb. Allow the gel to polymerize for $20 \mathrm{~min}$ at room temperature.

Preparation of Samples and Electrophoresis

7. Mix 5-20 $\mu$ g of total RNA sample with at least an equal volume of formamide loading buffer to a final volume of $10 \mu \mathrm{L}$.

The amount of total RNA sample to be used varies according to the abundance of the RNA to be detected.

8. Heat the mixture for $5 \mathrm{~min}$ at $95^{\circ} \mathrm{C}$, and then place the tubes on ice.

9. Wash the wells of the gel to remove urea. This is essential to produce uniform, straight bands. Then, carefully load $10 \mu \mathrm{L}$ of each RNA sample into each well of the gel. Be sure to include $5^{\prime}{ }^{32} \mathrm{P}-$ radiolabeled RNA Decade marker. Label the marker by T4 polynucleotide kinase and $\left[\gamma^{32} \mathrm{P}\right] \mathrm{ATP}$ according to the manufacturer's instructions, and then dilute 200 -fold to an activity appropriate for the small RNA to be detected by hybridization.

10. Run the gel in $0.5 \times \mathrm{TBE}$ buffer at $200 \mathrm{~V}$ until the bromophenol blue reaches the bottom of the gel $(\sim 1 \mathrm{~h})$.

Transferring RNA onto Membrane with a Semidry Transfer Cell

11. Cut a piece of Hybond $\mathrm{N}+$ nylon membrane and two pieces of extra thick blotting paper to the dimensions of the gel, and soak them in $0.5 \times$ TBE buffer for $10 \mathrm{~min}$ at room temperature.

12. Place one piece of presoaked, extra thick blotting paper on the platinum anode. Remove air bubbles by rolling the paper with a clean plastic pipette.

13. Place the presoaked membrane on top of the blotting paper, and roll out the air bubbles.

14. Carefully lay the gel on top of the membrane, and roll out the air bubbles.

15. Place the other piece of presoaked, extra thick blotting paper on top of the gel, and roll out the air bubbles.

16. Connect the cathode to the sandwich stack, and then place the safety cover on the unit. Transfer at constant voltage of $20 \mathrm{~V}$ for $1 \mathrm{~h}$. 
C. Li and P.D. Zamore

17. After transfer, place the damp membrane on a piece of filter paper, and cross-link the RNA to the membrane by irradiation with 254-nm UV light (Stratalinker; autocrosslink setting of 120,000 $\mu \mathrm{J}$ ).

UV cross-linking immobilizes the RNA on the membrane, allowing blots to be reprobed multiple times.

18. Place the cross-linked membrane into a hybridization tube with the RNA side facing the interior. Add $20 \mathrm{~mL}$ of Church buffer, place the tube into the hybridization oven, and incubate for $1 \mathrm{~h}$ to overnight at $37^{\circ} \mathrm{C}$ with rotation for prehybridization.

\section{Preparation of 5' 32P-Radiolabeled Oligonucleotide Probes}

19. The probe is perfectly complementary to the small RNA to be detected with the same length. Set up the $5^{\prime}$-end labeling reaction by mixing the following reagents:

$\begin{array}{ll}\text { Nuclease-free water } & 6 \mu \mathrm{L} \\ \text { DNA oligonucleotide probe }(25 \mu \mathrm{M}) & 1 \mu \mathrm{L} \\ \text { T4 polynucleotide kinase buffer }(10 \times) & 1 \mu \mathrm{L} \\ \text { T4 polynucleotide kinase }(10 \mathrm{U} / \mu \mathrm{L}) & 1 \mu \mathrm{L} \\ {\left[\gamma^{32} \mathrm{P}\right] \text { ATP }(6000 \mathrm{Ci} / \mathrm{mmol}, \geq 10 \mathrm{mCi} / \mathrm{mL})} & 1 \mu \mathrm{L}\end{array}$

20. Incubate the reaction for $1 \mathrm{~h}$ at $37^{\circ} \mathrm{C}$.

21. Remove unincorporated $\left[\gamma^{-}{ }^{32} \mathrm{P}\right]$ ATP with a Sephadex G-25 spin column according to the manufacturer's instructions.

\section{Preparation of $3^{\prime}$-End ${ }^{32} \mathrm{P}$-Labeled StarFire Oligonucleotide Probes (Optional)}

22. Resuspend the StarFire Universal Template to a concentration of $12.5 \mu \mathrm{M}$ with $1 \times$ TE buffer.

23. Resuspend the StarFire Custom Probe to a concentration of $100 \mu \mathrm{m}$ with $1 \times \mathrm{TE}$ buffer.

24. Dilute the StarFire Custom Probe to a concentration of $0.5 \mu \mathrm{m}$ with nuclease-free water.

25. Mix the following reagents in a $0.5-\mathrm{mL}$ microcentrifuge tube:

$\begin{array}{ll}\text { StarFire buffer }(10 \times) & 1 \mu \mathrm{L} \\ \text { StarFire probe }(0.5 \mu \mathrm{M}) & 1 \mu \mathrm{L} \\ \text { StarFire Universal Template }(12.5 \mu \mathrm{M}) & 1 \mu \mathrm{L}\end{array}$

26. Mix by pipetting, and then incubate the tube for $1 \mathrm{~min}$ in a $95^{\circ} \mathrm{C}$ heat block.

27. Remove the tube from the heat block, and allow the reaction to cool to room temperature ( $\sim 5 \mathrm{~min}$ ). Briefly centrifuge the tube to collect the reaction at the bottom of the tube.

28. Add $6 \mu \mathrm{L}$ of $\left[\alpha^{-32} \mathrm{P}\right] \mathrm{dATP}(6000 \mathrm{Ci} / \mathrm{mmol}, 10 \mathrm{mCi} / \mathrm{mL})$ and $1 \mu \mathrm{L}$ of Exo ${ }^{-}$Klenow DNA Polymerase. Mix by gently pipetting.

29. Incubate the tube at room temperature for $2 \mathrm{~h}$, and then $40 \mu \mathrm{L}$ of StarFire Stop Buffer.

30. Remove unincorporated $\left[\alpha-{ }^{32} \mathrm{P}\right] \mathrm{dATP}$ with a Sephadex G-25 spin column according to the manufacturer's instructions.

Hybridization

31. After prehybridization (Step 18), add either the $5^{\prime}{ }^{32} \mathrm{P}$-radiolabeled probe or the $3^{\prime}{ }^{32} \mathrm{P}$-radiolabeled StarFire probe directly to the prehybridization solution, and incubate for $2 \mathrm{~h}$ to overnight.

These are alternative methods. The 3'-radiolabeled StarFire probe is generally more sensitive than the 5'-radiolabeled probe of the same sequence.

Two hours of hybridization usually yields at least $80 \%$ of the maximum signal. For highest sensitivity, perform hybridization overnight.

32. After hybridization, carefully transfer the hybridization solution into a $50-\mathrm{mL}$ conical tube and store at $-20^{\circ} \mathrm{C}$.

33. Briefly rinse the bottle twice with $30 \mathrm{~mL}$ of $1 \times$ SSC plus $0.1 \%(\mathrm{w} / \mathrm{v})$ SDS. 
34. Wash the membrane with $30 \mathrm{~mL}$ of $1 \times$ SSC plus $0.1 \%(\mathrm{w} / \mathrm{v}) \mathrm{SDS}$ for $10 \mathrm{~min}$ at $37^{\circ} \mathrm{C}$. Repeat wash twice.

35. Wrap the damp membrane with Saran Wrap, and expose it to a PhosphorImager plate overnight.

36. Read the hybridization signals with a PhosphorImager (e.g., FUJI FLA-5000), and analyze hybridization using appropriate software (e.g., ImageGauge v4.22).

See Troubleshooting.

Analysis of the Relative Abundance of Small RNA in Different Samples

37. Quantify the original hybridization signal and the background noise of the same sample according to instructions for using ImageGauge. Subtract the background noise from the original hybridization signal to get the specific hybridization signal of the small RNA.

38. Strip the probe from the blot by boiling the membrane in $500 \mathrm{~mL}$ of $0.1 \%(\mathrm{w} / \mathrm{v}$ ) SDS for $10 \mathrm{~min}$. Wrap the damp membrane with Saran Wrap, and expose it to a PhosphorImager plate overnight to check if stripping was successful. Repeat this step if the signals were not completely erased.

39. Hybridize the membrane with a probe that is specific to an internal control (e.g., a small nuclear RNA, tRNA, or 5 S ribosomal RNA present in the same sample) to visualize specific hybridization signals of the internal control in each sample as described above.

40. Normalize the specific hybridization signal of the small RNA of interest to that of the internal control. The normalized values between different samples can now be compared to assess the relative abundance of the small RNA of interest.

Analysis of the Absolute Amount of Small RNA in a Sample

41. Order an RNA oligonucleotide with exactly the same sequences as the small RNA of interest, and make a series of dilutions $\left(10^{-1}-10^{3} \mathrm{fmol}\right)$.

42. Load the diluted RNA oligonucleotides and the samples on a denaturing polyacrylamide gel, and perform northern hybridization as described above (Steps 7-36).

43. Plot the specific hybridization signals (be sure to subtract background) of the diluted RNA oligonucleotides versus their concentrations to obtain a standard curve. Use this standard curve to determine the absolute amount of the small RNA in each sample.

In our experience, northern blots analyzed by Phosphorlmaging can be linear over as many as five logs of signal.

Most miRNAs and some abundant endo-siRNAs and piRNAs are readily detected with $5^{\prime 2} P$-radiolabeled DNA or RNA oligonucleotide probes. For low-abundance small RNAs, $3^{\prime}{ }^{32} P$-radiolabeled StarFire oligonucleotide probes or $5^{\prime 32} \mathrm{P}$-radiolabeled LNA-modified oligonucleotide probes are recommended.

Problem (Step 36): No signals are detected, but $5^{\prime}{ }^{32} \mathrm{P}$-radiolabeled markers are.

Solution: Try the following.

- Check whether the probe sequence is perfectly complementary to the small RNA of interest.

- Check if the probe is properly labeled by resolving it in a $15 \%$ denaturing polyacrylamide gel followed by PhosphorImagery.

- Check the internal loading control. 
C. Li and P.D. Zamore

- To increase sensitivity, use a $5^{\prime}$-end ${ }^{32} \mathrm{P}$-labeled RNA oligonucleotide probe or a $5^{\prime}$-end ${ }^{32} \mathrm{P}$-labeled LNA-modified DNA oligonucleotide probe, and increase the temperature to $60^{\circ} \mathrm{C}$ or $70^{\circ} \mathrm{C}$, respectively.

Problem (Step 36): High background hybridization signals are detected.

Solution: Extend the prehybridization to overnight. Repeat the last wash twice more.

The highest specific activity that can be obtained using polynucleotide kinase to catalyze the addition of ${ }^{32} \mathrm{P}$ to the $5^{\prime}$-OH group of an oligonucleotide is $\sim 1.3 \times 10^{7} \mathrm{cpm} / \mathrm{pmol}$. However $\sim 10$-fold higher specific activity can be obtained using StarFire-a commercial system to add multiple radiolabeled deoxyribonucleotide triphosphates (dNTPs) to the $3^{\prime}$ end of an investigator-defined oligonucleotide. These high-specific-activity probes are required to detect RNAs that are small in size and present in low abundance (e.g., miRNAs).

Starfire probes are generated as shown in Figure 2. In summary, an oligonucleotide is synthesized with a target sequence at its $5^{\prime}$ end and a universal template sequence at its $3^{\prime}$ end. A second oligonucleotide is then annealed to the universal template. The protruding single-stranded poly $(\mathrm{T})$ tail of the second oligonucleotide serves as a template in a primer extension reaction catalyzed by the exo ${ }^{-}$Klenow fragment of E. coli DNA polymerase I using $\alpha-{ }^{32} \mathrm{P}$-dATP as a substrate. As shown in

A Design and synthesis of oligonucleotides

1. Substrate oligonucleotide (probe)

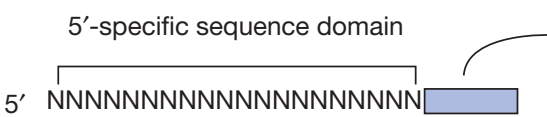

Universal template

binding domain

(same for all probes)

$5^{\prime}$ NNNNNNNNNNNNNNNNNNNN $\square 3^{\prime}$

2. Template oligonucleotide

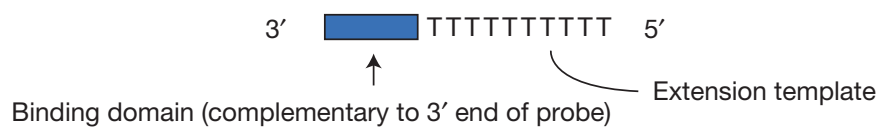

B Anneal probe + template in buffer

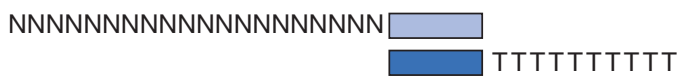

C Labeling/extension reaction

Add DNA polymerase $+\alpha-{ }^{32} \mathrm{P}-\mathrm{dATP}\left[{ }^{*} \mathrm{~A}\right]$.

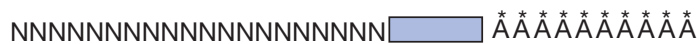

TTTTTTTTTT

D Remove unincorporated label using column chromatography.

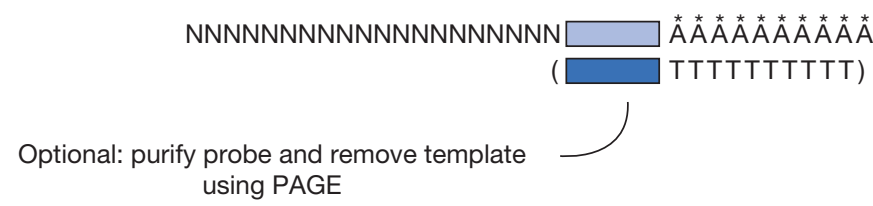

FIGURE 2. The StarFire oligonucleotide labeling protocol. (A) Two oligonucleotides are used in the reaction-a targetspecific probe oligonucleotide and a universal template oligonucleotide. The oligonucleotides are annealed $(B)$ and labeled in a primer extension reaction by DNA polymerase $(C)$. Unincorporated nucleotides are removed by gel filtration (D). (Redrawn from Belhke et al. 2000, with permission from BioTechniques.) 
Figure 2, up to 10 radiolabeled deoxynucleosides can be attached to an investigator-defined sequence, generating a single-stranded probe of specific size and very high specific activity.

\section{Ammonium Persulfate}

To prepare a $10 \%(\mathrm{w} / \mathrm{v})$ solution: Dissolve $1 \mathrm{~g}$ ammonium persulfate in $10 \mathrm{~mL}$ of $\mathrm{H}_{2} \mathrm{O}$ and store at $4^{\circ} \mathrm{C}$. Ammonium persulfate decays slowly in solution, so replace the stock solution every $2-3 \mathrm{wk}$. Ammonium persulfate is used as a catalyst for the copolymerization of acrylamide and bisacrylamide gels. The polymerization reaction is driven by free radicals generated by an oxido-reduction reaction in which a diamine (e.g., TEMED) is used as the adjunct catalyst.

\section{Church Buffer}

$1 \%(\mathrm{w} / \mathrm{v})$ bovine serum albumin

1 mм EDTA

$0.5 \mathrm{~m}$ phosphate buffer ${ }^{\star}$

$7 \%(\mathrm{w} / \mathrm{v})$ SDS

${ }^{\star} 0.5 \mathrm{M}$ phosphate buffer is $134 \mathrm{~g}$ of $\mathrm{Na}_{2} \mathrm{HPO}_{4} \cdot 7 \mathrm{H}_{2} \mathrm{O}, 4 \mathrm{~mL}$ of $85 \% \mathrm{H}_{3} \mathrm{PO}_{4}$ (concentrated phosphoric acid), $\mathrm{H}_{2} \mathrm{O}$ to $1 \mathrm{~L}$.

\section{Formamide Loading Buffer for RNA Gels}

Deionized formamide

EDTA (pH 8.0)

Xylene cyanol FF

$80 \%(\mathrm{w} / \mathrm{v})$

$10 \mathrm{~mm}$

Bromophenol blue

$1 \mathrm{mg} / \mathrm{mL}$

$1 \mathrm{mg} / \mathrm{mL}$

Purchase a distilled deionized preparation of formamide and store in small aliquots under nitrogen at $-20^{\circ} \mathrm{C}$.

Alternatively, deionize reagent-grade formamide by stirring on a magnetic stirrer with Dowex XG8 mixed bed resin for $1 \mathrm{~h}$ and filtering it twice through Whatman No. 1 paper. Store deionized formamide in small aliquots under nitrogen at $-70^{\circ} \mathrm{C}$.

$S D S$

Also called sodium dodecyl sulfate or sodium lauryl sulfate. To prepare a $20 \%(\mathrm{w} / \mathrm{v})$ solution, dissolve $200 \mathrm{~g}$ of electrophoresis-grade SDS in $900 \mathrm{~mL}$ of $\mathrm{H}_{2} \mathrm{O}$. Heat to $68^{\circ} \mathrm{C}$ and stir with a magnetic stirrer to assist dissolution. If necessary, adjust the $\mathrm{pH}$ to 7.2 by adding a few drops of concentrated $\mathrm{HCl}$. Adjust the volume to $1 \mathrm{~L}$ with $\mathrm{H}_{2} \mathrm{O}$. Store at room temperature. Sterilization is not necessary. Do not autoclave.

\section{SSC}

For a $20 \times$ solution: Dissolve $175.3 \mathrm{~g}$ of $\mathrm{NaCl}$ and $88.2 \mathrm{~g}$ of sodium citrate in $800 \mathrm{~mL}$ of $\mathrm{H}_{2} \mathrm{O}$. Adjust the $\mathrm{pH}$ to 7.0 with a few drops of a $14 \mathrm{~N}$ solution of $\mathrm{HCl}$. Adjust the volume to $1 \mathrm{~L}$ with $\mathrm{H}_{2} \mathrm{O}$. Dispense into aliquots. Sterilize by autoclaving. The final concentrations of the ingredients are $3.0 \mathrm{M} \mathrm{NaCl}$ and $0.3 \mathrm{~m}$ sodium citrate. 
C. Li and P.D. Zamore

T4 Polynucleotide Kinase Buffer (10x)

$700 \mathrm{~mm}$ Tris- $\mathrm{Cl}$ (pH 7.6)

$100 \mathrm{~mm} \mathrm{MgCl}_{2}$

$50 \mathrm{~mm}$ DTT

Store at $-20^{\circ} \mathrm{C}$ in small aliquots.

TBE Buffer

Prepare a $5 \times$ stock solution in $1 \mathrm{~L}^{\text {of }} \mathrm{H}_{2} \mathrm{O}$ :

$54 \mathrm{~g}$ of Tris base

$27.5 \mathrm{~g}$ of boric acid

$20 \mathrm{~mL}$ of $0.5 \mathrm{~m}$ EDTA (pH 8.0)

The $0.5 \times$ working solution is $45 \mathrm{~mm}$ Tris-borate/ $1 \mathrm{~mm}$ EDTA.

TBE is usually made and stored as a $5 \times$ or $10 \times$ stock solution. The $\mathrm{pH}$ of the concentrated stock buffer should be $\sim 8.3$. Dilute the concentrated stock buffer just before use and make the gel solution and the electrophoresis buffer from the same concentrated stock solution. Some investigators prefer to use more concentrated stock solutions of TBE $(10 \times$ as opposed to $5 \times)$. However, $5 \times$ stock solution is more stable because the solutes do not precipitate during storage. Passing the $5 \times$ or $10 \times$ buffer stocks through a $0.22-\mu \mathrm{m}$ filter can prevent or delay formation of precipitates.

TE Buffer, 10×

$100 \mathrm{~mm}$ Tris- $\mathrm{Cl}$ (desired $\mathrm{pH})$

10 mM EDTA (pH 8.0)

Sterilize solutions by autoclaving for $20 \mathrm{~min}$ at $15 \mathrm{psi}\left(1.05 \mathrm{~kg} / \mathrm{cm}^{2}\right)$ on liquid cycle. Store the buffer at room temperature. 


\section{Analysis of Small RNAs by Northern Hybridization}

Chengjian Li and Phillip D. Zamore

Cold Spring Harb Protoc; doi: 10.1101/pdb.prot097493

\begin{tabular}{rc}
$\begin{array}{r}\text { Email Alerting } \\
\text { Service }\end{array}$ & Receive free email alerts when new articles cite this article - click here. \\
\hline $\begin{array}{c}\text { Subject } \\
\text { Categories }\end{array}$ & Browse articles on similar topics from Cold Spring Harbor Protocols. \\
& Analysis of Gene Expression (197 articles) \\
& Analysis of Gene Expression, general (129 articles) \\
& Blots (66 articles) \\
& Electrophoresis (57 articles) \\
& Electrophoresis of Nucleic Acids (62 articles) \\
& Electrophoresis of RNA (23 articles) \\
& Molecular Biology, general (1293 articles) \\
& RNA (317 articles) \\
& RNA, general (269 articles) \\
\hline
\end{tabular}

